\title{
The role of COP1 in repression of photoperiodic flowering
}

\section{[version 1; peer review: 2 approved]}

\section{Dongqing Xu, Danmeng Zhu, Xing Wang Deng}

State Key Laboratory of Protein and Plant Gene Research, Peking-Tsinghua Center for Life Sciences, School of Advanced Agriculture Sciences and School of Life Sciences, Peking University, Beijing, China

V1 First published: 16 Feb 2016, 5(F1000 Faculty Rev):178

https://doi.org/10.12688/f1000research.7346.1

Latest published: 16 Feb 2016, 5(F1000 Faculty Rev):178

https://doi.org/10.12688/f1000research.7346.1

\section{Abstract}

Plants use the circadian clock as a timekeeping mechanism to regulate photoperiodic flowering in response to the seasonal changes. CONSTITUTIVELY PHOTOMORPHOGENIC 1 (COP1), initially identified as a central repressor of seedling photomorphogenesis, was recently shown to be involved in the regulation of light input to the circadian clock, modulating the circadian rhythm and flowering. COP1 encodes a RING-finger E3 ubiquitin ligase and works in concert with SUPPRESSOR of phyA-105 (SPA) proteins to repress photoperiodic flowering by regulating proteasome-mediated degradation of CONSTANS (CO), a central regulator of photoperiodic flowering. In addition, COP1 and EARLY FLOWERING 3 (ELF3) indirectly modulate CO expression via the degradation of GIGANTEA (GI). Here, we summarize the current understanding of the molecular mechanisms underlying COP1's role in controlling of photoperiodic flowering.

\section{Keywords}

COP1, photoperiodic flowering, CONSTITUTIVE

PHOTOMORPHOGENIC 1 , flowering time

\section{Open Peer Review \\ Approval Status \\ 1 \\ 2 \\ version 1 \\ 16 Feb 2016 \\ Faculty Reviews are review articles written by the prestigious Members of Faculty Opinions. The articles are commissioned and peer reviewed before publication to ensure that the final, published version is comprehensive and accessible. The reviewers who approved the final version are listed with their names and affiliations.}

\footnotetext{
1. Haiyang Wang, Chinese Academy of

Agricultural Sciences, Beijing, China

2. Nam-Chon Paek, Seoul National University,

Seoul, South Korea

Any comments on the article can be found at the end of the article.
} 
Corresponding author: Xing Wang Deng (deng@pku.edu.cn)

Competing interests: The authors declare that they have no competing interests.

Grant information: This work was supported by National Natural Science Foundation of China (31330048) and the National Institutes of Health (GM047850).

The funders had no role in study design, data collection and analysis, decision to publish, or preparation of the manuscript.

Copyright: $\odot 2016$ Xu D et al. This is an open access article distributed under the terms of the Creative Commons Attribution License, which permits unrestricted use, distribution, and reproduction in any medium, provided the original work is properly cited.

How to cite this article: $X u D$, Zhu D and Deng XW. The role of COP1 in repression of photoperiodic flowering [version 1; peer review: 2 approved] F1000Research 2016, 5(F1000 Faculty Rev):178 https://doi.org/10.12688/f1000research.7346.1

First published: 16 Feb 2016, 5(F1000 Faculty Rev):178 https://doi.org/10.12688/f1000research.7346.1 


\section{Introduction}

In plants, the phase transition from vegetative to reproductive development is controlled by multiple environmental cues, including photoperiod, light quality, and temperature ${ }^{1}$. According to their flowering response to the photoperiod change, plants could be classified as long-day (LD) plants, short-day (SD) plants, and day-neutral plants, respectively ${ }^{2}$. At present, most advances regarding the flowering-time control were obtained in the model facultative LD plant Arabidopsis and the model SD plant rice. A central regulator of LD-induced flowering is the B-box zinc finger transcription factor CONSTANS (CO), which positively regulates flowering time by upregulating the expression of "florigen" FLOWERING LOCUS $T(F T)$ in Arabidopsis ${ }^{3}$. The control of $\mathrm{CO}$ abundance by circadian clock and light plays a crucial role in regulating flowering.

CONSTITUTIVELY PHOTOMORPHOGENIC 1 (COP1) was initially identified as a key repressor of photomorphogenesis over 20 years ago in Arabidopsis ${ }^{4,5}$. The subsequent characterization of COP1 revealed its function in multiple light-mediated developmental processes in Arabidopsis and other higher plants, including circadian rhythm and flowering ${ }^{6,7}$. The ortholog of Arabidopsis COP1 was also found to play vital roles in regulating a variety of developmental processes in animals. COP1 encodes a RING-finger E3 ubiquitin ligase. In Arabidopsis, COP1 functions together with SUPPRESSOR of phyA-105 (SPA) proteins to target the photomorphogenesis-promoting factors for degradation via the 26S proteasome system, such as ELONGATED HYPOCOTYL 5 (HY5), LONG AFTER FAR-RED LIGHT 1 (LAF1), and LONG HYPOCOTYL IN FAR-RED 1 (HFR1) $)^{8-11}$.

\section{The relationship of photoreceptors and COP1 in flowering}

In Arabidopsis, far-red and red light is perceived by phytochromes (phyA-phyE) ${ }^{12,13}$; blue light is sensed by cryptochromes (CRY1 and CRY2) and several new photoperiodic and/or circadian photoreceptors: ZEITLUPE (ZTL), FLAVIN-BINDING, KELCH REPEAT, F-BOX 1 (FKF1), and LOV, KELCH PROTEIN 2 $(\mathrm{LKP} 2)^{14}$. It was reported that phyA and CRYs are two classes of principal photoperiodic photoreceptors that promote flowering. Mutations in these genes reduce the accumulation of $\mathrm{CO}$ protein and delay flowering ${ }^{15,16}$. During photomorphogenesis, CRYs suppress the activity of the multifunctional E3 ubiquitin ligase COP1 by dissociating the formation of COP1-SPA complex(es), thereby repressing its E3 ubiquitin ligase activity to regulate gene expression in response to blue light ${ }^{17-19}$. In flowering transition, blue light-dependent CRY2-SPA1 interaction stimulates CRY2-COP1 association to suppress the COP1-dependent proteolysis of $\mathrm{CO}^{19}$. However, how phyA mediates light regulation of protein degradation to modulate developmental timing in flowering is unclear at present. In contrast to cry2, the early-flowering phenotype of phyB in $\mathrm{SD}$ is possibly resulting from a COP1-independent mechanism ${ }^{15,16,20}$. Paradoxically, plants overexpressing phyB also show early flowering, in which the Pfr form of phyB inhibits COP1SPA activity to stabilize $\mathrm{CO}$ and subsequently induce $F T$ expression by phyB-SPA1 direct interaction ${ }^{21}$.

\section{COP1 direct targets in modulation of flowering}

$\mathrm{CO}$ acts as a central regulator of photoperiodic flowering, and its abundance directly correlates with the timing of flowering. $\mathrm{CO}$ is precisely regulated at both transcriptional and post-translational levels, and this is crucial for Arabidopsis to discriminate the photoperiod and response to light.

The expression of $C O$ is regulated by circadian clock-associated components, including GIGANTEA (GI), the F-box protein FKF1, and CYCLING DOF FACTORS (CDFs), which regulate daily $C O$ expression profiles ${ }^{22-24}$. EARLY FLOWERING 3 (ELF3) acts as a substrate adaptor to allow COP1-GI interaction, which leads to the degradation of GI by COP $1^{25}$. FKF1 forms a complex with GI in a light-dependent manner, which contributes to control the $C O$ transcript level by mediating the degradation of $C O$ transcriptional repressors, $\mathrm{CDFs}^{22-24}$. Thus, degradation of GI by COP1 may result in the disassociation of FKF1-GI complex and then negatively regulate $C O$ expression.

Post-translational regulation of $\mathrm{CO}$ is another aspect for controlling flowering in response to day length. copl mutants display early-flowering phenotype under $\mathrm{SD}$, which is largely related to the change of CO abundance. During the day, CO protein is stabilized, whereas at night $\mathrm{CO}$ protein is rapidly degraded through the $26 \mathrm{~S}$ proteasome pathway mediated by COP1. COP1 directly interacts with the $\mathrm{C}$-terminal of $\mathrm{CO}$ in phloem companion cells, where FT protein moves to induce flowering at the shoot apex ${ }^{26,27}$. In addition, the early-flowering phenotype of spal is enhanced by the lesion in SPA3 and SPA4. SPA proteins negatively modulate $\mathrm{CO}$ abundance so that spal spa3 spa4 triple mutants exhibit strongly increased $\mathrm{CO}$ protein levels ${ }^{28}$. A recent report further demonstrated that the COP1-SPA complex(es) directly interact with the phosphorylated form of $\mathrm{CO}$ protein to trigger its protein turnover ${ }^{29}$.

In the early morning, TARGET OF EAT (TOE) proteins associate with the transcriptional activation domain of $\mathrm{CO}$ to inhibit its activity $^{30}$. FKE1 stabilizes the $\mathrm{CO}$ abundance through a direct interaction in the late afternoon of $\mathrm{LD}^{31}$. At night, $\mathrm{CO}$ is degraded through the ubiquitin-mediated 26S proteasome system. Consistently, $\mathrm{CO}$ protein levels and its direct target $F T$ peak in the afternoon under LD conditions ${ }^{32}$. CO activates $F T$ expression mainly through two modes of action: (1) $\mathrm{CO}$ directly binds to the CO-responsive element (CORE) in the promoter of FT to activate its expression ${ }^{33}$. (2) CO physically interacts with two other $F T$ activators NUCLEAR FACTOR-Y (NF-Y) and Myb transcription factor ASYMMETRIC LEAVES 1 (AS1), which directly bind to $F T$ promoter, thus promoting their activation on $F T^{34,35}$. COP1 triggers the protein turnover of $\mathrm{CO}$, in turn disrupting the formation of CO-NF-Y and $\mathrm{CO}-\mathrm{AS} 1$ complexes and eventually repressing the $F T$ expression.

Besides light, temperature is another important environmental indicator to determine the appropriate time to flower. Recent work showed that COP1 could act as an integrator of light and cold temperature. copl mutants exhibit reduced sensitivity to changes in ambient temperatures in an FT-dependent manner in Arabidopsis. 
At low ambient temperatures, COP1 is stabilized and subsequently promotes the degradation of GI, which directly activates $F T$ expression to promote flowering ${ }^{36}$.

\section{COP1-related factors in control of flowering}

Similar to COP1, another repressor of photomorphogenesis, DE-ETIOLATE 1 (DET1), functions as a negative regulator of flowering, as det1 mutants flower early in both LD and SD (extremely early in SD) $)^{37}$. DET1 was shown to be part of the COP10, DE-ETIOLATE 1, DAMAGED DNA-BINDING PROTEIN 1 (CDD) complex, working as CUL4-based E3 ligase ${ }^{38}$. Co-suppression mutants of CUL4 also showed early-flowering phenotype under SD conditions. CUL4-DDB1 also associates with COP1-SPA complexes ${ }^{39}$. Together, these studies indicate that a series of E3 ligase complexes may work in concert to repress flowering.

Recent studies revealed that, besides COP1, another RING-finger containing E3 ubiquitin ligase, HIGH EXPRESSION OF OSMOTICALLY RESPONSIVE GENES 1 (HOS1), is also involved in controlling the $\mathrm{CO}$ protein levels. In the morning of $\mathrm{LD}$, phyB-mediated red light signaling activates HOS1 to degrade $\mathrm{CO}^{40}$. However, on the night of $\mathrm{SD}, \mathrm{CO}$ protein is ubiquitinated and degraded by COP1-SPA complexes. Consistently, hos 1 copl double mutants display complete photoperiodic insensitivity, suggesting that HOS1 and COP1 function synergistically in the control of flowering time ${ }^{41,42}$. Moreover, a regulator of the TOPOISOMERASE VI complex, MIDGET (MID), physically interacts with COP1 and is required for $\mathrm{COP} 1$ function as a repressor of flowering under SD conditions $^{43}$.

In SD plant rice, PETER PAN SYNDROME (PPS) encodes an ortholog of Arabidopsis COP1. Although PPS is similar to COP1 in repressing photomorphogenesis ${ }^{44}$, it controls photoperiodic flowering by HEADING DATE 1 (Hd1) (ortholog of Arabidopsis CO) via a currently unknown mechanism ${ }^{45}$.

\section{Future perspectives}

Extensive studies have revealed a complicated but delicate network in regulating photoperiodic flowering in plants. After the role of COP1 in repressing light responses at seedling stage by the regulation of proteolysis was established, later advances have greatly expanded its implication in the control of photoperiodic flowering and circadian rhythm. The studies mentioned in this review have also raised a number of challenging questions to be addressed in the future. As a long-term goal, the roles of COP1 in light quality control of flowering would be of great interest to determine. Specifically, how does COP1 work in concert or function antagonistically with other key factors to control $\mathrm{CO}$ abundance/activity in a special photoperiod or in response to multiple environmental cues? How does COP1 determine the substrates to be degraded by the COP1-SPA complex alone or together by other COP/DET/FUS protein-containing complex(es)? Moreover, the identification and characterization of novel direct targets of COP1 in the control of photoperiodic flowering will assist us in understanding the molecular mechanism underlying CO-independent pathways. In addition, further studies on the differential mechanisms of COP1 function in Arabidopsis and crop plants will help us to explore their functional novelty and diversity during the evolution of monocots and dicots.

\section{Abbreviations}

AS1, ASYMMETRIC LEAVES 1; CDF, CYCLING DOF FACTOR; CO, CONSTANS; COP1, CONSTITUTIVE PHOTOMORPHOGENIC 1; CRY, cryptochromes; CUL4, CULLIN4; DET1, DE-ETIOLATE 1; FKF1, FLAVIN BINDING, KELCH REPEAT, F-BOX 1; FT, FLOWERING LOCUS T; GI, GIGANTEA; HOS1, HIGH EXPRESSION OF OSMOTICALLY RESPONSIVE GENES 1; LD, long-day; MID, MIDGET; PPS, PETER PAN SYNDROME; NF-Y, NUCLEAR FACTOR-Y; PHY, phytochromes; SD, short-day; SPA, SUPPRESSOR of phyA-105.

\section{Competing interests}

The authors declare that they have no competing interests.

\section{Grant information}

This work was supported by the National Natural Science Foundation of China (31330048) and the National Institutes of Health (GM047850).

I confirm that the funders had no role in study design, data collection and analysis, decision to publish, or preparation of the manuscript.

\section{Acknowledgments}

We apologize to the colleagues whose work could not be cited because of space limitations.
1. Romera-Branchat M, Andrés F, Coupland G: Flowering responses to seasona cues: what's new? Curr Opin Plant Biol. 2014; 21: 120-7. PubMed Abstract | Publisher Full Text

2. Simpson GG, Gendall AR, Dean C: When to switch to flowering. Annu Rev Cell Dev Biol. 1999; 15: 519-50. PubMed Abstract | Publisher Full Text

3. F Song YH, Shim JS, Kinmonth-Schultz HA, et al:: Photoperiodic flowering: time measurement mechanisms in leaves. Annu Rev Plant Biol. 2015; 66: 441-64. PubMed Abstract | Publisher Full Text | Free Full Text | F1000 Recommendation

4. Deng XW, Caspar T, Quail PH: cop1: a regulatory locus involved in light-controlled development and gene expression in Arabidopsis. Genes Dev. 1991; 5(7): 1172-82.

PubMed Abstract | Publisher Full Text
5. Deng XW, Matsui M, Wei N, et al.: COP1, an Arabidopsis regulatory gene, encodes a protein with both a zinc-binding motif and a $\mathrm{G}$ beta homologous domain. Cell. 1992; 71(5): 791-801.

PubMed Abstract | Publisher Full Text

6. Lau OS, Deng XW: The photomorphogenic repressors COP1 and DET1: 20 years later. Trends Plant Sci. 2012; 17(10): 584-93. PubMed Abstract | Publisher Full Text

7. Huang $X$, Ouyang $X$, Deng XW: Beyond repression of photomorphogenesis: role switching of COP/DET/FUS in light signaling. Curr Opin Plant Biol. 2014; 21: 96-103. switching of COP/DET/FUS in light sign
PubMed Abstract | Publisher Full Text

8. Osterlund MT, Hardtke CS, Wei N, et al:: Targeted destabilization of HY5 during light-regulated development of Arabidopsis. Nature. 2000; 405(6785): 462-6. PubMed Abstract | Publisher Full Text 
9. $\quad \mathrm{F}$ Seo HS, Yang JY, Ishikawa M, et al.: LAF1 ubiquitination by COP1 controls photomorphogenesis and is stimulated by SPA1. Nature. 2003; 423(6943): 995-9. PubMed Abstract | Publisher Full Text | F1000 Recommendation

10. F Jang IC, Yang JY, Seo HS, et al:: HFR1 is targeted by COP1 E3 ligase for post-translational proteolysis during phytochrome A signaling. Genes Dev. 2005; 19(5): 593-602.

PubMed Abstract | Publisher Full Text | Free Full Text | F1000 Recommendation

11. Zhu D, Maier A, Lee JH, et al.: Biochemical characterization of Arabidopsis complexes containing CONSTITUTIVELY PHOTOMORPHOGENIC1 and SUPPRESSOR OF PHYA proteins in light control of plant development. Plant Cell. 2008; 20(9): 2307-23.

PubMed Abstract | Publisher Full Text | Free Full Text

12. Bae G, Choi G: Decoding of light signals by plant phytochromes and their interacting proteins. Annu Rev Plant Biol. 2008; 59: 281-311.

PubMed Abstract | Publisher Full Text

13. Chen M, Chory J: Phytochrome signaling mechanisms and the control of plant development. Trends Cell Biol. 2011; 21(11): 664-71.

PubMed Abstract | Publisher Full Text | Free Full Text

14. Liu $\mathrm{H}$, Liu B, Zhao $\mathrm{C}$, et al:: The action mechanisms of plant cryptochromes. Trends Plant Sci. 2011; 16(12): 684-91.

PubMed Abstract | Publisher Full Text | Free Full Text

15. F Valverde F, Mouradov A, Soppe W, et al:: Photoreceptor regulation of CONSTANS protein in photoperiodic flowering. Science. 2004; 303(5660): 1003-6. PubMed Abstract | Publisher Full Text | F1000 Recommendation

16. F Mockler TC, Guo H, Yang H, et al:: Antagonistic actions of Arabidopsis cryptochromes and phytochrome $B$ in the regulation of floral induction. Development. 1999; 126(10): 2073-82.

PubMed Abstract |F1000 Recommendation

17. F Lian HL, He SB, Zhang YC, et al.: Blue-light-dependent interaction of cryptochrome 1 with SPA1 defines a dynamic signaling mechanism. Genes Dev. 2011; 25(10): 1023-8.

PubMed Abstract | Publisher Full Text | Free Full Text | F1000 Recommendation

18. F Liu B, Zuo Z, Liu H, et al: Arabidopsis cryptochrome 1 interacts with SPA1 to suppress COP1 activity in response to blue light. Genes Dev. 2011: 25(10): 1029-34. PubMed Abstract | Publisher Full Text | Free Full Text | F1000 Recommendation

19. F Zuo Z, Liu H, Liu B, et al:: Blue light-dependent interaction of CRY2 with SPA1 regulates COP1 activity and floral initiation in Arabidopsis. Curr Biol. 2011; 21(10): 841-7.

PubMed Abstract | Publisher Full Text | Free Full Text | F1000 Recommendation

20. Reed JW, Nagatani A, Elich TD, et al.: Phytochrome A and Phytochrome B Have Overlapping but Distinct Functions in Arabidopsis Development. Plant Physiol. 1994: 104(4): 1139-49.

PubMed Abstract | Free Full Text

21. F Hajdu A, Ádám É, Sheerin DJ, et al.: High-level expression and phosphorylation of phytochrome B modulates flowering time in Arabidopsis. Plant J. 2015 83(5): 794-805.

PubMed Abstract | Publisher Full Text | F1000 Recommendation

22. F Imaizumi T, Schultz TF, Harmon FG, et al:: FKF1 F-box protein mediates cyclic degradation of a repressor of CONSTANS in Arabidopsis. Science. 2005 309(5732): 293-7.

PubMed Abstract | Publisher Full Text | F1000 Recommendation

23. Sawa M, Nusinow DA, Kay SA, et al.: FKF1 and GIGANTEA complex formation is required for day-length measurement in Arabidopsis. Science. 2007; 318(5848) 261-5.

PubMed Abstract | Publisher Full Text | Free Full Text

24. Fornara F, Panigrahi KC, Gissot L, et al:: Arabidopsis DOF transcription factors act redundantly to reduce CONSTANS expression and are essential for a photoperiodic flowering response. Dev Cell. 2009; 17(1): 75-86.

PubMed Abstract | Publisher Full Text

25. Yu JW, Rubio V, Lee NY, et al:: COP1 and ELF3 control circadian function and photoperiodic flowering by regulating GI stability. Mol Cell. 2008; 32(5): 617-30. PubMed Abstract | Publisher Full Text | Free Full Text

26. Jang S, Marchal V, Panigrahi KC, et al:: Arabidopsis COP1 shapes the tempora pattern of $\mathrm{CO}$ accumulation conferring a photoperiodic flowering response. EMBO J. 2008; 27(8): 1277-88.

PubMed Abstract | Publisher Full Text | Free Full Text

27. F Liu LJ, Zhang YC, Li QH, et al:: COP1-mediated ubiquitination of CONSTANS is implicated in cryptochrome regulation of flowering in Arabidopsis. Plant Cell. 2008; 20(2): 292-306

PubMed Abstract | Publisher Full Text | Free Full Text | F1000 Recommendation
28. F Laubinger S, Marchal V, Le Gourrierec J, et al: Arabidopsis SPA proteins regulate photoperiodic flowering and interact with the flora inducer CONSTANS to regulate its stability. Development. 2006; 133(16): 3213-22.

PubMed Abstract | Publisher Full Text | F1000 Recommendation

29. F Sarid-Krebs L, Panigrahi KC, Fornara F, et al.: Phosphorylation of CONSTANS and its COP1-dependent degradation during photoperiodic flowering of Arabidopsis. Plant J. 2015; 84(3): 451-63.

PubMed Abstract | Publisher Full Text | F1000 Recommendation

30. F Zhang B, Wang L, Zeng L, et al:: Arabidopsis TOE proteins convey a photoperiodic signal to antagonize CONSTANS and regulate flowering time. Genes Dev. 2015; 29(9): 975-87.

PubMed Abstract | Publisher Full Text | Free Full Text | F1000 Recommendation

31. F Song $\mathrm{YH}$, Smith RW, To BJ, et al.: FKF1 conveys timing information for CONSTANS stabilization in photoperiodic flowering. Science. 2012; 336(6084): 1045-9.

PubMed Abstract | Publisher Full Text | Free Full Text | F1000 Recommendation

32. F Salazar JD, Saithong T, Brown PE, et al:: Prediction of photoperiodic egulators from quantitative gene circuit models. Cell. 2009; 139(6): 1170-9. PubMed Abstract | Publisher Full Text | F1000 Recommendation

33. $\mathrm{F}$ Tiwari $\mathrm{SB}$, Shen $\mathrm{Y}$, Chang $\mathrm{HC}$, et al:: The flowering time regulator CONSTANS is recruited to the FLOWERING LOCUS $T$ promoter via a unique cis-element. New Phytol. 2010; 187(1): 57-66. PubMed Abstract | Publisher Full Text | F1000 Recommendation

34. F Wenkel S, Turck F, Singer K, et al.: CONSTANS and the CCAAT box binding complex share a functionally important domain and interact to regulate flowering of Arabidopsis. Plant Cell. 2006; 18(11): 2971-84. PubMed Abstract | Publisher Full Text | Free Full Text | F1000 Recommendation

35. F Song YH, Lee I, Lee SY, et al:: CONSTANS and ASYMMETRIC LEAVES 1 complex is involved in the induction of FLOWERING LOCUS $T$ in photoperiodic flowering in Arabidopsis. Plant J. 2012; 69(2): 332-42. PubMed Abstract | Publisher Full Text | Free Full Text | F1000 Recommendation

36. F Jang K, Lee HG, Jung SJ, et al:: The E3 Ubiquitin Ligase COP1 Regulates Thermosensory Flowering by Triggering GI Degradation in Arabidopsis. Sci Rep. 2015; 5: 12071.

PubMed Abstract | Publisher Full Text | Free Full Text | F1000 Recommendation

37. F Kang MY, Yoo SC, Kwon HY, et al.: Negative regulatory roles of DE-ETIOLATED1 in flowering time in Arabidopsis. Sci Rep. 2015; 5: 9728. PubMed Abstract | Publisher Full Text | Free Full Text | F1000 Recommendation

38. Chen $\mathrm{H}$, Shen $\mathrm{Y}$, Tang $\mathrm{X}$, et al:: Arabidopsis CULLIN4 Forms an E3 Ubiquitin Ligase with RBX1 and the CDD Complex in Mediating Light Control of Development. Plant Cell. 2006; 18(8): 1991-2004.

PubMed Abstract | Publisher Full Text | Free Full Text

39. Chen H, Huang X, Gusmaroli G, et al:: Arabidopsis CULLIN4-damaged DNA binding protein 1 interacts with CONSTITUTIVELY PHOTOMORPHOGENIC1SUPPRESSOR OF PHYA complexes to regulate photomorphogenesis and flowering time. Plant Cell. 2010; 22(1): 108-23. PubMed Abstract | Publisher Full Text | Free Full Text

40. F Lazaro A, Valverde F, Piñeiro M, et al:: The Arabidopsis E3 ubiquitin ligase HOS1 negatively regulates CONSTANS abundance in the photoperiodic control of flowering. Plant Cell. 2012; 24(3): 982-99. PubMed Abstract | Publisher Full Text | Free Full Text | F1000 Recommendation

41. F Jung JH, Seo PJ, Park CM: The E3 ubiquitin ligase HOS1 regulates Arabidopsis flowering by mediating CONSTANS degradation under cold stress. J Biol Chem. 2012; 287(52): 43277-87. PubMed Abstract | Publisher Full Text | Free Full Text | F1000 Recommendation

42. F Jung JH, Lee HJ, Park MJ, et al:: Beyond ubiquitination: proteolytic and nonproteolytic roles of HOS1. Trends Plant Sci. 2014; 19(8): 538-45. PubMed Abstract | Publisher Full Text | F1000 Recommendation

43. F Schrader A, Uhrig J: MIDGET cooperates with COP1 and SPA1 to repress flowering in Arabidopsis thaliana. Plant Signal Behav. 2013; 8(9): pii: e25600. PubMed Abstract | Publisher Full Text | Free Full Text | F1000 Recommendation

44. Tsuge $\mathrm{T}$, Inagaki N, Yoshizumi T, et al:: Phytochrome-mediated control of COP1 gene expression in rice plants. Mol Genet Genomics. 2001; 265(1): 43-50. PubMed Abstract | Publisher Full Text

45. F Tanaka $\mathrm{N}$, Itoh $\mathrm{H}$, Sentoku $\mathrm{N}$, et al:: The COP1 ortholog PPS regulates the juvenile-adult and vegetative-reproductive phase changes in rice. Plant Cell. 2011; 23(6): 2143-54

PubMed Abstract | Publisher Full Text | Free Full Text | F1000 Recommendation 


\section{Open Peer Review}

\section{Current Peer Review Status:}

\section{Editorial Note on the Review Process}

Faculty Reviews are review articles written by the prestigious Members of Faculty Opinions. The articles are commissioned and peer reviewed before publication to ensure that the final, published version is comprehensive and accessible. The reviewers who approved the final version are listed with their names and affiliations.

\section{The reviewers who approved this article are:}

\section{Version 1}

\section{Nam-Chon Paek}

Department of Plant Science, Research Institute of Agriculture and Life Sciences, Seoul National University, Seoul, South Korea

Competing Interests: No competing interests were disclosed.

\section{Haiyang Wang} Institute of Crop Science, Chinese Academy of Agricultural Sciences, Beijing, China

Competing Interests: No competing interests were disclosed.

The benefits of publishing with F1000Research:

- Your article is published within days, with no editorial bias

- You can publish traditional articles, null/negative results, case reports, data notes and more

- The peer review process is transparent and collaborative

- Your article is indexed in PubMed after passing peer review

- Dedicated customer support at every stage

For pre-submission enquiries, contact research@f1000.com 